\title{
A New Era for Ribavirin Aerosols to Treat Respiratory Syncitial Virus Infections in Immunocompromised Patients?
}

Ribavirin is an old drug that was developed and approved in the late 1980s to treat respiratory syncitial virus infections. It can be administered orally, intravenously, or by inhalation using a nebulizer. At the time it was developed, continuous nebulization was considered a valuable method to administer inhaled drugs in critical conditions, ${ }^{1}$ using large volume nebulizers. In the case of ribavirin, the small-particle aerosol generator- 2 was demonstrated in vitro to be efficient ${ }^{2}$ and was thereafter the only device used in units that adopted the aerosol route. During the last few years, this treatment has been revisited. New clinical data support the efficiency of aerosolized ribavirin to treat respiratory syncitial virus infections in immunocompromised hematopoietic cell transplant recipients ${ }^{3-5}$ and in patients with cancer. ${ }^{6}$

In 2012, Chemaly et al ${ }^{6}$ introduced the possibility of administering aerosolized ribavirin, still with the smallparticle aerosol generator- 2 but intermittently, in the form of $2 \mathrm{~g}$ over $3 \mathrm{~h}$ every $8 \mathrm{~h}$ daily, rather than continuously (ie, $6 \mathrm{~g}$ over $18 \mathrm{~h}$ daily). This study was then criticized in a letter published in the same journal by Fätkenheuer et al, ${ }^{7}$ who pointed out that there are still no placebo-controlled studies to demonstrate firmly the clinical efficiency of aerosolized ribavirin. Furthermore, they questioned the validity of the study by Chemaly et al, ${ }^{6}$ which had finally concluded that intermittent administration was superior to continuous administration.

It is not that clear therefore where we stand today with regard to the use of aerosolized ribavirin to treat respiratory syncitial virus infection, and at the moment, aerosolized ribavirin is not the standard treatment. In France, for example, this practice seems to be very limited or even completely absent.

Despite this uncertainty, the study by Walsh et al, ${ }^{8}$ published in this issue of Respiratory CARE, is interesting because it tests further the possibility of administering aerosolized ribavirin in much shorter periods of time, us-

\footnotetext{
The authors have disclosed no conflicts of interest.
}

Correspondence: Patrice Diot MD PhD, Service de Pneumologie, Hôpital Bretonneau, 2 boulevard Tonnellé, 37044 Cedex 9, Tours, France. E-mail: diot@med.univ-tours.fr.

DOI: $10.4187 /$ respcare.04797 ing the modern technology of vibrating mesh nebulizers. ${ }^{9}$ This technology has proven its interest in critical care situations, and there are clear grounds for extending its use to the administration of anti-infectious agents. ${ }^{10,11}$

\section{See the Original Study on Page 577}

With the small-particle aerosol generator-2, which is used with a drying chamber, ribavirin is diluted in a large volume of sterile water. The evaporation that occurs during the process of nebulization avoids the exposure of human tissues to hypotonic particles, which can induce adverse effects, such as cough and bronchospasm. ${ }^{8}$

The Aeroneb ProX, which was compared with the smallparticle aerosol generator- 2 in an experimental bench model in the study by Walsh et al, ${ }^{8}$ is a small-volume vibrating mesh nebulizer, which does not allow a hypotonic solution to evaporate during the nebulization process. The authors therefore decided to dilute ribavirin in $0.9 \%$ saline. They demonstrated that using saline instead of water does not alter the physicochemical characteristics of ribavirin, either before or after nebulization. They also demonstrated the equivalence in terms of total drug delivery between the small-particle aerosol generator-2 and the Aeroneb ProX, in both spontaneous and mechanical ventilation conditions, suggesting the possibility of dramatically reducing the time required to administer the medication. This study was conducted according to best laboratory practice, which makes it a valuable basis for further developments.

However, one must emphasize that many steps are still needed before any firm conclusion can be drawn, as the authors themselves stress in the so-called limitations of their study. Any change in medication requires going through the whole approval process again in order for the drug to be available on the ground, which is time- and money-consuming. The experience with aerosolized ciclosporin over the last $20 \mathrm{y}$ demonstrates how difficult it can be. ${ }^{12}$ It certainly requires the commitment of a manufacturer attracted by a possible new market. Unfortunately, this question of market and manufacturer might be an issue in the context of ribavirin, considering that promising new drugs to treat respiratory syncitial virus infections are currently being developed and tested. 


\section{AEROSOLIZED RIBAVIRIN FOR RSV}

It would also require high-standard clinical studies, including placebo-controlled trials, which have not yet been conducted, even with the aqueous solution and the recommended small-particle aerosol generator-2 device. Moreover, multi-center studies should be conducted because the current literature on the subject only comes from 2 or so groups.

It will be very interesting to observe what will happen following the study by Walsh et al. ${ }^{8}$ If successful, it could be the first case of therapeutic progress stimulated by technological developments.

Patrice Diot MD PhD

Université François Rabelais CEPR / INSERM UMR1100

Department of Pulmonology

CHU de Tours

Tours, France

Laurent Plantier MD PhD

Université François Rabelais

CEPR / INSERM UMR1100

Department of Pulmonology

CHU de Tours

Tours, France

\section{REFERENCES}

1. Portnoy J, Nadel G, Amado M, Willsie-Ediger S. Continuous nebulization for status asthmaticus. Ann Allergy 1992;69(1):71-79.

2. Newth CJ, Clark AR. In vitro performance of the small particle aerosol generator (SPAG-2). Pediatr Pulmonol 1989;7(3):183-188.
3. Shah DP, Ghantoji SS, Shah JN, El Taoum KK, Jiang Y, Popat U, et al. Impact of aerosolized ribavirin on mortality in 280 allogeneic haematopoietic stem cell transplant recipients with respiratory syncytial virus infections. J Antimicrob Chemother 2013;68(8):18721880.

4. Chemaly RF, Shah DP, Boeckh MJ. Management of respiratory viral infections in hematopoietic cell transplant recipients and patients with hematologic malignancies. Clin Infect Dis 2014;59(Suppl 5): S344-S351.

5. Seo S, Campbell AP, Xie H, Chien JW, Leisenring WM, Englund JA, Boeckh M. Outcome of respiratory syncytial virus lower respiratory tract disease in hematopoietic cell transplant recipients receiving aerosolized ribavirin: significance of stem cell source and oxygen requirement. Biol Blood Marrow Transplant 2013;19(4):589-596.

6. Chemaly RF, Torres HA, Munsell MF, Shah DP, Rathod DB, Bodey GP, et al. An adaptive randomized trial of an intermittent dosing schedule of aerosolized ribavirin in patients with cancer and respiratory syncytial virus infection. J Infect Dis 2012;206(9):1367-1371.

7. Fätkenheuer G, Gillor D, Platten M, Kochanek M, Salzberger B. Aerosolized ribavirin for patients with cancer and respiratory syncytial virus infection. J Infect Dis 2013;207(10):1621.

8. Walsh BK, Betit P, Fink JB, Pereira LM, Arnold J. Characterization of ribavirin aerosols with small-particle aerosol generator and vibrating mesh micropump aerosol technologies. Respir Care 2016;61(5):577585 .

9. Martin AR, Finlay WH. Nebulizers for drug delivery to the lungs. Expert Opin Drug Deliv 2015;12(6):889-900.

10. Ehrmann S, Roche-Campo F, Bodet-Contentin L, Razazi K, Dugernier J, Trenado-Alvarez J, et al. Aerosol therapy in intensive and intermediate care units: prospective observation of 2808 critically ill patients. Intensive Care Med. 2016;42(2):192-201

11. Boukhettala N, Porée T, Diot P, Vecellio L. In vitro performance of spacers for aerosol delivery during adult mechanical ventilation. J Aerosol Med Pulm Drug Deliv 2015;28(2):130-136.

12. Iacono AT, Johnson BA, Grgurich WF, Youssef JG, Corcoran TE, Seiler DA, et al. A randomized trial of inhaled cyclosporine in lungtransplant recipients. N Engl J Med 2006;354(2):141-150. 